\author{
C. Hernández-Sánchez $\cdot$ A. Mansilla • \\ E. J. de la Rosa $\cdot$ F. de Pablo
}

\title{
Proinsulin in development: new roles for an ancient prohormone
}

Received: 4 July 2005 / Accepted: 27 September 2005 / Published online: 5 April 2006

C) Springer-Verlag 2006

\begin{abstract}
In postnatal organisms, insulin is well known as an essential anabolic hormone responsible for maintaining glucose homeostasis. Its biosynthesis by the pancreatic beta cell has been considered a model of tissue-specific gene expression. However, proinsulin mRNA and protein have been found in embryonic stages before the formation of the pancreatic primordium, and later, in extrapancreatic tissues including the nervous system. Phylogenetic studies have also confirmed that production of insulin-like peptides antecedes the morphogenesis of a pancreas, and that these peptides contribute to normal development. In recent years, other roles for insulin distinct from its metabolic function have emerged also in vertebrates. During embryonic development, insulin acts as a survival factor and is involved in early morphogenesis. These findings are consistent with the observation that, at these stages, the proinsulin gene product remains as the precursor form, proinsulin. Independent of its low metabolic activity, proinsulin stimulates proliferation in developing neuroretina, as well as cell survival and cardiogenesis in early embryos. Insulin/proinsulin levels are finely regulated during development, since an excess of the protein interferes with correct morphogenesis and is deleterious for the embryo. This fine-tuned regulation is achieved by the expression of alternative embryonic proinsulin transcripts that have diminished translational activity.
\end{abstract}

Keywords Cardiogenesis - Cell death - Development . Embryo - Evolution - Gene expression - Growth - Hybrid receptors $\cdot$ Insulin $\cdot$ Proinsulin

C. Hernández-Sánchez $(\bowtie) \cdot$ A. Mansilla

E. J. de la Rosa · F. de Pablo

Group of Growth Factors in Vertebrate Development,

Centre of Biological Investigations (CIB),

Spanish Council for Research (CSIC),

Ramiro de Maeztu 9,

E-28040 Madrid, Spain

e-mail: chernandez@cib.csic.es

Tel: +34-91-5349201

Fax: +34-91-5349201
Abbreviations AUG: methionine codon PC: protein convertase · upAUG: upstream AUG - UTR: untranslated region

We who study developmental biology are the inheritors of embryology's concepts, organisms and sense of wonder. From other sources, we have received a new set of tools with resolving power far greater than what was available a generation ago.

Scott F. Gilbert, 1991

A Conceptual History of Modern Embryology

\section{As time goes by}

Twenty-five years ago, one of us, then a young postdoctoral fellow, arrived at the National Institutes of Health in Bethesda (MD, USA), thinking that she would work on the dysfunction of receptors in insulin-resistant patients. Having trained as a clinical endocrinologist, the first conversation with the Diabetes Branch chief, Jesse Roth, her tutor for the next 2 years, was a shock. Roth, who was an Evo-Devo [1] pioneer without knowing it himself, told the naïve fellow that insulin might have arisen millions of years ago in evolution and, therefore, be present in primitive organisms lacking even a pancreas. Indeed, together with Derek LeRoith, who is now chief of the Division of Endocrinology and Diabetes at The Mount Sinai School of Medicine, he, Roth, had found molecules similar to mammalian insulin in the heads of flies and in nematodes [2]. The astonished young postdoctoral fellow could not maintain a defensive sceptical attitude for very long.

Insulin, it seemed, could be more than a hormone, maybe a conserved signalling gene product, and its cellular functions represent essential mechanisms in evolution and development. A big role for a small-sized protein! The enthusiasm over this broad view of insulin's role in phylogeny was not universal. It was easier to see how right, 
and clearly ahead of their time, were some of Roth's and colleagues views on hormones and receptors [3], after the completed sequences of the genomes of Drosophila melanogaster [4] and Caenorhabditis elegans [5] confirmed that the production of insulin-like peptides precedes in evolution the morphogenesis of a pancreas, and that these peptides contribute to normal development.

As another former fellow of the Diabetes Branch at NIH recently wrote, in a thorough historical perspective of more than three decades of research into the structural biology of insulin-receptor interaction, 'insulin proved to be a bonanza for protein chemists and...may arguably deserve the title of protein of the 20th century' [6]. Insulin, we agree, does deserve a special place among molecules that have opened new biochemical and biological avenues for understanding life. When insulin was the first protein to have its primary amino acid sequence resolved, by Fred Sanger in 1953 [7], it could not be anticipated that besides saving the lives of millions of insulin-dependent diabetic patients, it would be a universal survival protein for cells in culture [8], and also become a paradigm for studies on gene expression, protein processing and regulated protein secretion.

Postnatally in vertebrates, insulin is an essential anabolic hormone responsible for maintaining glucose homeostasis. Its biosynthesis by pancreatic beta cells is a model of tissue-specific gene expression. The mature beta cells are the 'insulin factory' of the organism $[9,10]$, where high levels of proinsulin are transcribed and translated. The primary protein product, proinsulin, matures to insulin through processing executed by the endopeptidases protein convertase (PC)2 and PC3, and is accumulated in the secretory granules, which respond to regulated secretion signals. Circulating insulin levels are largely dependent on food intake, and glucose, among other metabolites, is the central regulator of pancreatic insulin biosynthesis at multiple steps [11]. The important action of insulin as a pancreatic hormone might have diverted recognition of other relevant roles played by insulin, either earlier in life, during development, or locally in tissues such as the nervous system. Here, we present an update of what insulin, its precursor proinsulin and insulin receptors have taught us about their developmental nonmetabolic functions.

\section{Insulin across animal kingdoms}

The insulin-related peptide family represents a group of structurally similar molecules with a characteristic hydrophobic core and six cysteine residues. In the human genome, the insulin-related gene family comprises ten members: in addition to the best characterised proinsulin and IGF1 and -2 , seven peptides related to relaxin have been found [12]. Focusing our attention on the closest relatives to insulin, strong evidence suggests that proinsulin, IGF1 and IGF2 have evolved by gene duplication from a common ancestor gene [13]. These three proteins present high amino acid-sequence identity [14, 15], homologue tyrosine kinase receptors $[16,17]$ and overlapping intracellular signalling pathways $[18,19]$. These peptides affect multiple and diverse biological functions including metabolism, cell size, cell proliferation, differentiation, survival and growth, both during development and in adult organisms [20-23].

Recently, molecular genetics techniques have allowed the phylogenetic origin of the proinsulin gene to be determined (reviewed in [13]). Insulin-like peptides and insulin receptor-like complementary DNAs have been identified in organisms that diverted from vertebrates a long time ago, including insects, molluscs and nematodes. The insulin family of proteins can be traced to the early multicellular eukaryotes [24], whereas no insulin-like genes have been found in the yeast genome [25]. Therefore, this gene family appears to have co-evolved with the appearance of the metazoan branch. Amphioxus, the postulated ancestor from which vertebrates evolved, has a single insulin-like peptide gene that is equally similar to insulin and IGFs [26]. Accordingly, the insulin receptorlike protein in amphioxus presents comparable amino acid homology to the human insulin and IGF1 receptors, and it is equally activated by human insulin and IGF1 [27]. Thus, the amphioxus insulin-like peptide and its receptor may be the ancestral genes from which vertebrate insulin, IGFs, and their corresponding receptor genes were derived. The high conservation between IGF1 and IGF2 amino acid sequences suggests that they originated as a result of a more recent gene duplication event during vertebrate phylogeny [28].

Frequently, several insulin-like peptide genes are found in invertebrates, although only one insulin-like receptor protein may emerge. The expression of some of those molecules is not restricted to the gut tissue, but it is also detected in neural cells. Thus, insulin-like peptides are considered neuroendocrine modulators associated with development and cell growth. In addition, insulin-like peptide signalling is also involved in reproductive function and longevity. Mutations of the insulin-like receptor in $D$. melanogaster and C. elegans increase the life span of the organism, an observation that has been reproduced in mouse IGF1 receptor heterozygotic null mutations [29-31]. Chan and Steiner [13] proposed that the ancestral insulin-like gene product function served primarily as a mitogenic growth factor but, after gene duplication, the mitogenic activity was retained by the vertebrate IGFs. This allowed the insulin gene product to develop a new function, the regulation of metabolism, and IGFs to become the main drivers of fetal and postnatal growth [32]. Some experimental data support the notion that this diversification and functional relay found in evolution is also present in development (review, see [33]).

\section{Insulin throughout an organism's life}

In recent years, alternative functions to insulin's role as a pancreatic hormone have been elucidated (reviewed in [23, $34,35])$. In parallel to these novel functions, investigators 
have begun to describe new mechanisms of the regulation of proinsulin gene expression. These actions and regulatory mechanisms appear to be reminiscent of those found in invertebrates. In this part of the review, we will focus on proinsulin/insulin expression and function in early embryonic stages of vertebrates (Table 1).

\section{Prepancreatic and extrapancreatic proinsulin expression in early development}

In several vertebrate species, proinsulin mRNA is first detected before the formation of the pancreatic primordium [36-39], and later in development, in extrapancreatic tissues [40-45]. Although prepancreatic and extrapancreatic proinsulin gene expression is much lower than in the pancreas [36], proinsulin mRNA can be unequivocally detected in the chick embryo as early as 0.5 day of embryonic development (Fig. 1a), corresponding to gastrulation [46], as well as in the retinal neuroepithelium at embryonic day 3 [47]. Proinsulin protein is detected in discrete cells located in the three embryonic layers but, mainly, in the neuroepithelium [46, 48] (Fig. 1b). Remarkably, a broad presence of proinsulin mRNA and protein is observed prior to IGF1 expression (Fig. 1) [46, 48]. Conversely, both insulin and IGF1 receptor mRNA are expressed at early developmental stages [49] (Fig. 2) and the corresponding tyrosine-kinase activity can be measured upon ligand binding [50]. Proinsulin mRNA expression also precedes IGF1 mRNA expression in the embryonic chick retina, while the transcripts for both receptors are expressed simultaneously [43, 51] (Fig. 2b).

Concerning its translation product, proinsulin remains unprocessed in the neurulating embryo and the neuroretina, due to lack of expression of at least one of the prohormone convertases, namely PC2 [44, 48]. The livers of mid- and late-stage chick embryos also lack PC2 expression, and preferentially yield proinsulin [44]. Muglia and Locker [40] found similar amounts of proinsulin and insulin produced by the yolk sac of late gestational rats. Since young embryos usually lack typical endocrine granules [52], prepancreatic and extrapancreatic proinsulin is likely to be secreted by a constitutive secretory pathway. In cultured neuroretina, rapid proinsulin secretion to the medium and accumulation occur in a few hours, even in the absence of secretagogues [53].

Table 1 Proinsulin and insulin in life stages

\begin{tabular}{lll}
\hline & Embryo & Postnatal \\
\hline Function & Survival & Metabolic \\
Active form & Proinsulin & Insulin \\
Regulation & Alternative transcripts & $\begin{array}{c}\text { Glucose activates } \\
\text { gene expression }\end{array}$ \\
& & Insulin receptor \\
Receptor & Atypical, hybrid & \\
& receptor likely & \\
\hline
\end{tabular}

\section{Receptors mediating proinsulin/insulin signals in early embryos}

Membrane-bound receptor and signalling pathways mediating proinsulin action in early development are less well studied than those of insulin. Binding studies in the chick neuroretina, whose size allows biochemical approaches with primary tissue, revealed an unexpected scenario. Proinsulin may act through heterodimeric or 'hybrid' insulin/IGF1 receptors formed by one $\alpha / \beta$ monomer of the insulin receptor and another $\alpha / \beta$ monomer of the IGF1 receptor. In the neuroretina, heterodimeric receptors are found at early stages, when the homodimeric insulin receptor is apparently absent. The proportion of hybrid receptors demonstrated by crosslinking decreases as retinal development proceeds, and homodimeric insulin receptors become demonstrable by immunoprecipitation [54]. Interestingly, classical binding-displacement studies revealed this atypical class of receptor that not only binds insulin and IGF1 with equivalent high affinity, but also recognises proinsulin with medium to high affinity $\left(\mathrm{EC}_{50}\right.$ of $\left.10^{-8} \mathrm{~mol} / \mathrm{l}\right)$ [54] (Fig. 2c). Hybrid insulin/IGF1 receptors have also been described in postnatal tissues of other species $[55,56]$. However, the binding characteristics of the known mammalian hybrid receptors differ from those found in the proliferative neuroretina, since they have higher affinity for IGF1 than for insulin. Pandini et al. [57] suggest that the insulin receptor splicing isoform may confer differences in ligand affinity of the hybrid receptor. This heterogeneity of the insulin receptor family, which provides possible alternative signalling mechanisms, fits nicely with the expanding physiological roles of insulin/proinsulin.

Preliminary studies have shown that Akt, a signalling molecule activated downstream of canonical insulin receptors in metabolic target tissues, is also implicated in the survival action of insulin during development. Akt phosphorylation is increased in proliferative neuroretina [51] and neurulating embryos (unpublished data of the authors) after addition of insulin. The specific proinsulin signalling pathway triggered by proinsulin during development deserves further study.

\section{Developmental mechanisms of the regulation of proinsulin gene expression}

The regulation of proinsulin gene expression in early embryogenesis also differs from its pancreatic regulation. In postnatal organisms, the plasma glucose concentration controls insulin expression at multiple levels. Glucose stimulates proinsulin gene transcription [58], as well as insulin mRNA processing and stability [59]. Initiation and elongation rates of insulin protein synthesis in the pancreas are also stimulated by glucose [60-62]. In contrast, embryonic proinsulin mRNA levels are not glucosedependent but developmentally regulated [63], an observation that indicates alternative mechanisms of regulation. Indeed, the use of alternative transcription start sites in embryonic extrapancreatic tissues has been reported [40, 

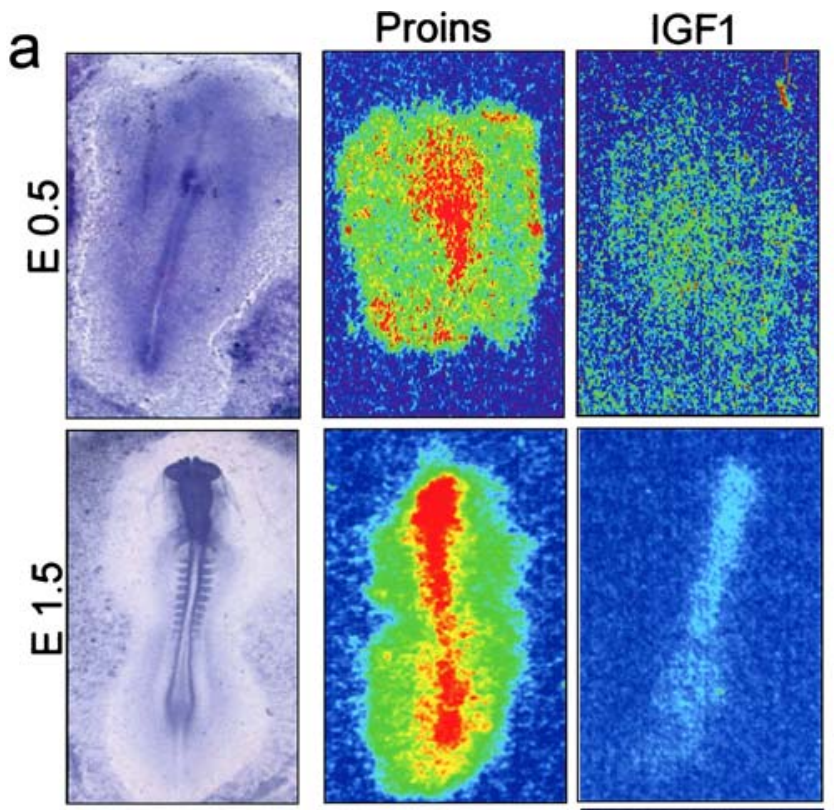

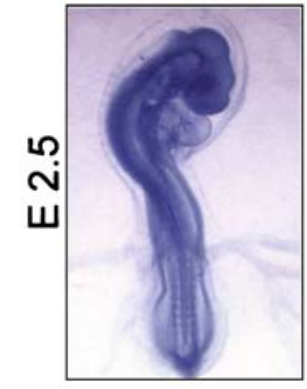

b
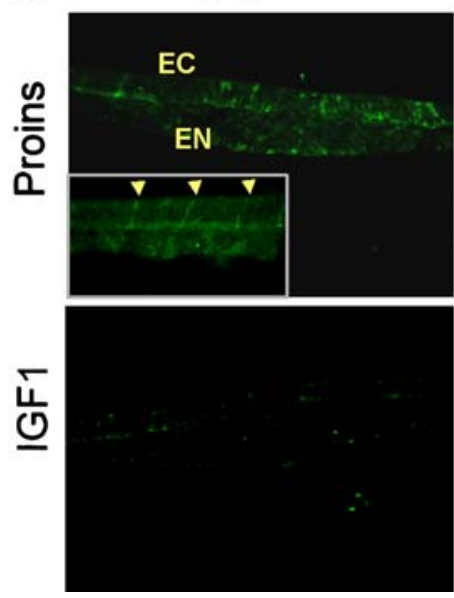

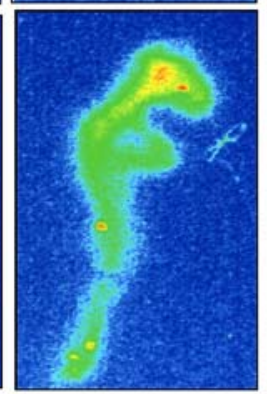

E 2.5
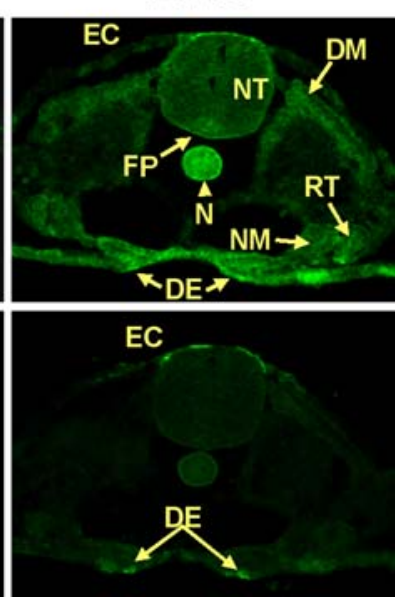

41, 48]. We have found two alternative, embryonic-specific transcripts (Pro1B and Pro1B1) in the neurulating chick embryo, also present in the mouse embryo (Fig. 3). An alternative transcription start site generates an embryonic proinsulin mRNA (Pro1B) with an extended 5' untranslated region (UTR), which nonetheless shares the coding region with pancreatic mRNA (Pro1A) [48]. Translation from this embryonic transcript is efficiently repressed by two methionine codons (AUGs) upstream (upAUG) to the proinsulin AUG [64] (Fig. 3). The constrained translation
Fig. 1 Proinsulin and IGF1 expression in early chick embryo development. a In situ hybridisation of proinsulin (Proins) and IGF1 in chick embryos at different embryonic days of development $(E)$. E0.5 corresponds to gastrulation, E1.5 to neurulation and E2.5 to early organogenesis. Arrows indicate the pancreatic buds. The pseudocolour scale reflects the highest signal in red and the lowest in blue. Reprinted with permission from [46] (copyright 1997, The Endocrine Society). b Immunostaining of Proins and IGF1, with mid-level transversal cryosections of E1 embryos and transversal cryosections of E2.5 embryos caudal to vitelline arteries. The insert shows a higher magnification detail of the E1 section and arrowheads indicate neuroepithelial cells. Note that proinsulin mRNA and protein are detected prior to the pancreatic bud formation and antecede IGF1 expression. $D E$, digestive endoderm; $D M$, dermamyotome; $E C$, ectoderm; $E N$, endoderm; $F P$, floor plate; $N$, notochord; $N M$ nephrogenic mesenchyme; $N T$, neural tube; $R T$ nephric tube. Reprinted with permission from [48] (copyright 2002, The American Diabetes Association)

imposed by upAUGs has been found in other proteins with critical functions [65-67]. In the case of embryonic proinsulin, moderate proinsulin excess induces embryonic malformations (Fig. 4b-e) [64], and larger amounts of proinsulin and insulin are teratogenic in embryos in early organogenesis [68], supporting a physiological function for translational repression. The other alternative transcript (Pro1B1) is generated by retention of the first intron in the $5^{\prime}$ UTR, resulting in a large and structured 5' UTR that nearly blocks proinsulin translation (Fig. 3) [69]. The use of multiple and developmental-specific promoters or transcription start sites has been extensively described for both IGF1 and IGF2 [70]. They provide alternative mechanisms for developmental stage- or tissue-specific expression of genes with critical proliferation or survival functions.

\section{Biological functions of proinsulin/insulin in early development}

In the last 20 years, an increasing number of observations has been published supporting the physiological role of insulin signalling in embryonic development. Both blocking anti-insulin antibodies and an excess of insulin are deleterious for growth in the chick embryo $[68,71]$. In cultured rat embryos, low insulin levels cause retarded growth and development [72]. More recent studies showed that downregulation of proinsulin mRNA or insulin receptor mRNA by antisense oligodeoxynucleotides results in an increase in cell death and developmental delay in the neurulating chick embryo (Fig. 4f-h) [46, 48], whereas in ovo treatment with blocking anti-insulin or anti-insulin receptor antibodies increases cell death and decreases neuronal numbers in the embryonic chick retina (Fig. 5) [51]. In parallel to this major role in survival/death control, insulin and proinsulin may also play a role in early morphogenesis and cardiogenesis [69, 73, 74]. Moreover, human fetuses lacking insulin receptor are significantly growth-retarded, showing a stronger phenotype than the insulin receptor knockout mouse (reviewed in [75]). Differences in developmental and organ maturation patterns may account for this discrepancy. 
a

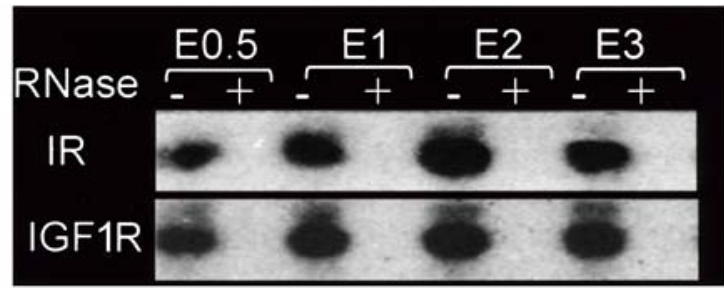

b

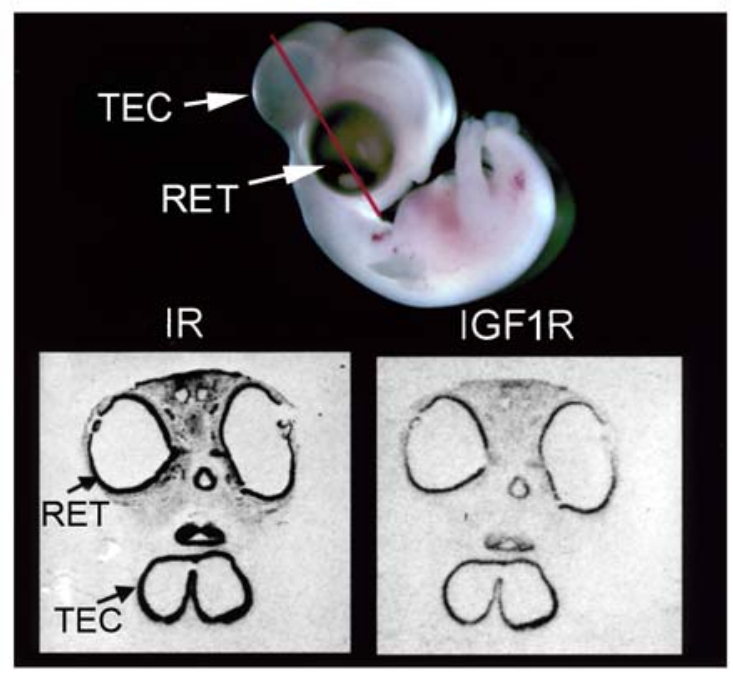

C

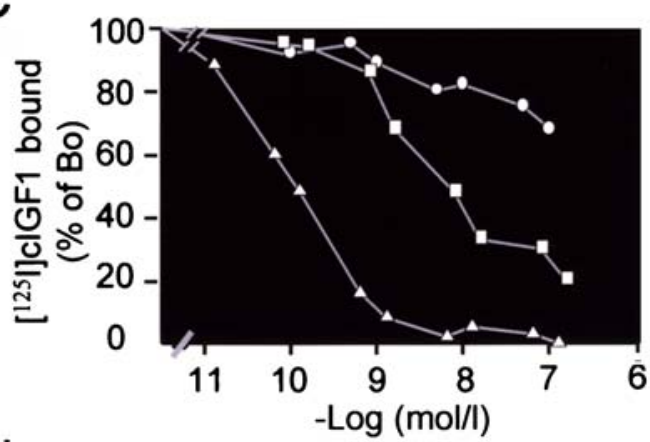

d

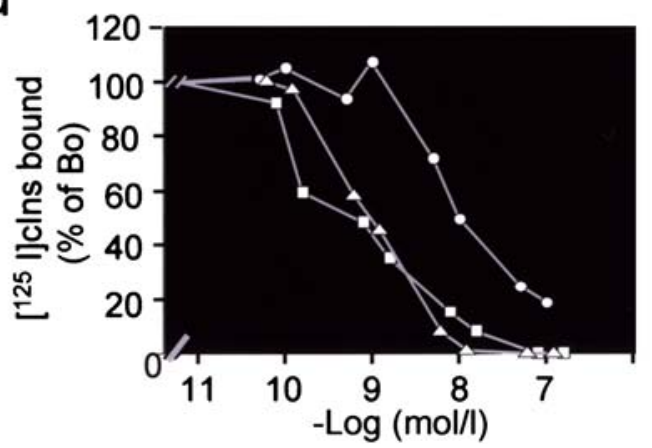

It is worth noting that proinsulin, being a metabolically low-activity insulin precursor [76], stimulates both growth of proliferating neuroretina in culture, with a potency only slightly lower than that of insulin or IGF1 [53], and cardiogenesis in the early embryo [69]. Proinsulin is also nearly as effective as insulin in preventing cell death in cultured neurulating embryos under growth factor deprivation conditions [48]. In a pharmacologically opposite approach, an excess of proinsulin is harmful to the embryo
Fig. 2 Insulin and IGF1 receptors expression in the developing chick embryo and retina. a RT-PCR followed by Southern blot analysis of RNA from the indicated embryonic day of development $(E)$ of chick embryos. $I R$, insulin receptor; $I G F 1 R$, IGF1 receptor. RNase treatment confirmed the absence of genomic DNA contamination. Reprinted with permission from [49]. b E6 embryo photography (above), and in situ hybridisation of IR and IGF1R in horizontal E6 embryo head sections, approximately at the level indicated in photography. RET, retina; TEC, optic tectum. Reprinted with permission from [43] (copyright 1994, Eur J Neurosci). Binding-competition curves for IGF1 (c) and insulin (Ins) (d). Crude membranes of E6 neuroretina were incubated with ${ }^{125}$ I-IGF1 or ${ }^{125}$ I-insulin tracer in the absence or presence of unlabelled human proinsulin (open circles), chicken insulin (open squares) or chicken IGF1 (open triangles) as competitors. $M, \mathrm{~mol} / \mathrm{l}$. Reprinted with permission from [54] (copyright 1999, The Endocrine Society)

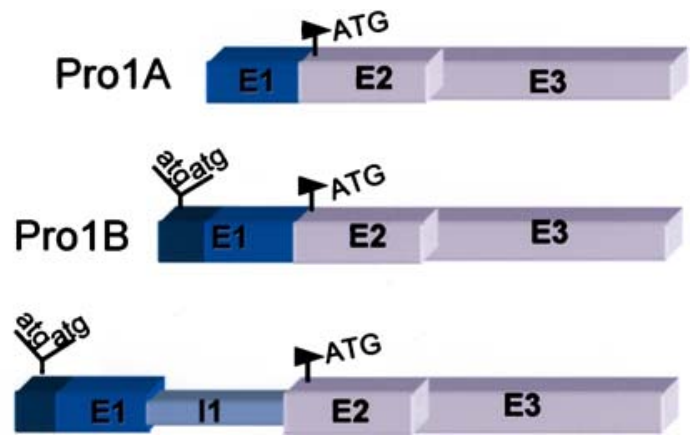

Fig. 3 Scheme of proinsulin transcripts. The pancreatic (ProlA) and embryonic (ProlB and ProlB1) chick proinsulin mRNAs: exons $(E)$, introns $(I)$. The common exons 2 and 3 are in grey and the variable exon $1\left(5^{\prime} \mathrm{UTR}\right)$ is in blue. The proinsulin translation initiation codon (ATG), as well as the two upstream ATGs (atg) are indicated

and interferes with correct morphogenesis, probably due to an excessive reduction in cell death (Fig. 4b-e) [64]. These unexpected biological roles of proinsulin fit very nicely with the observations on lack of proinsulin protein processing in retina and early embryo [44, 48].

\section{Relevance and challenges ahead}

The studies reviewed here define a broader and new scenario for the biological roles of proinsulin/insulin (Table 1). Proinsulin mRNA is present in the early embryo before the pancreas differentiates and in extrapancreatic tissues, in particular the neural tissue. The translation product, unprocessed proinsulin, appears to bind a promiscuous hybrid receptor, activating cell survival mechanisms during critical neurulation and neurogenesis processes, and inducing expression of cardiac genes; this has a strong impact on cell survival and embryo development. Precise, embryonic-specific regulation of the proinsulin gene and protein leads to the right amount to maintain adequate levels of cell death. We view proinsulin's embryonic action as the first wave of the multiple overlapping roles that the precursor and, later, mature insulin have in the life cycle of an organism (Fig. 6).

The clinical relevance of pancreatic insulin dysfunction is undisputed. The studies on prepancreatic and extra- 

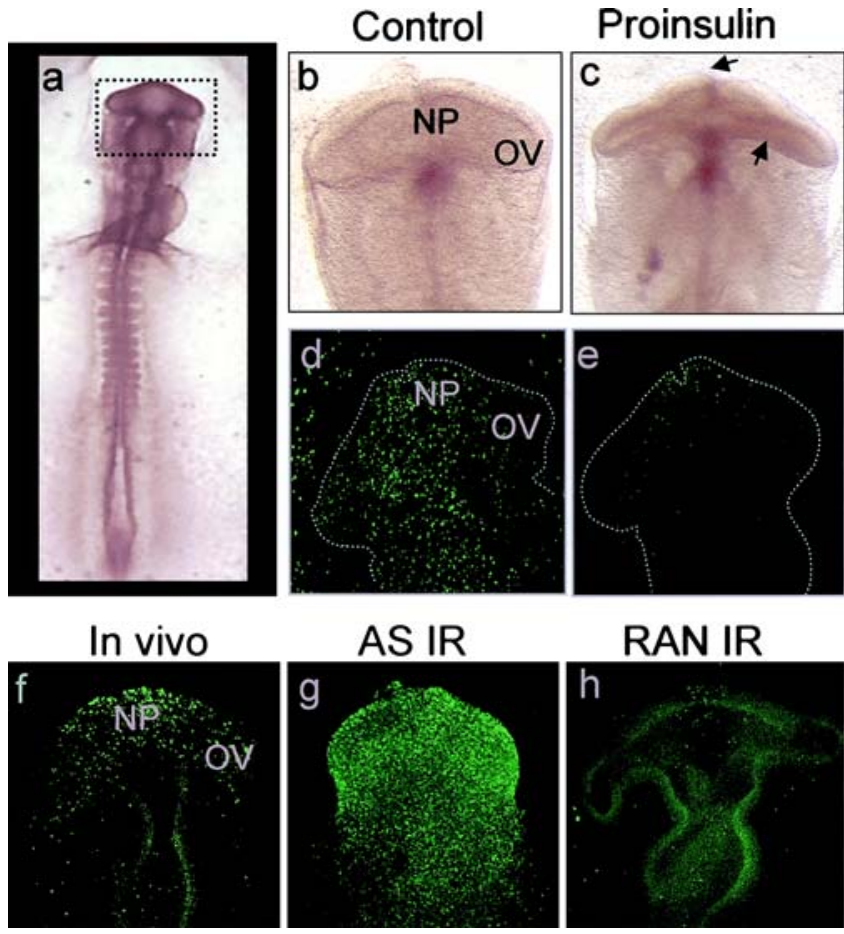

AS IR
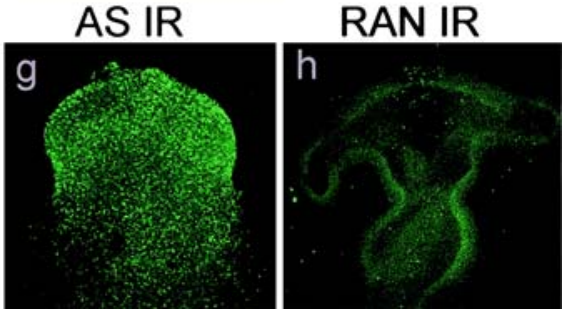

Fig. 4 Proinsulin/insulin effect on cell death in early chick embryo. a Embryo diagram, with inset of regions magnified $(\mathbf{b}-\mathbf{e})$. Developmental abnormalities (b-e) observed in E1.5 neurulating chick embryos after $8 \mathrm{~h}$ treatment in ovo with $50 \mu \mathrm{ll} 10^{-7} \mathrm{~mol} / \mathrm{l}$ human proinsulin. Frequent abnormalities included neural tube defects such as asymmetric anterior neuropore closure, collapsed optic vesicles (b, c), and flexures in the neural tube. These effects are consistent with a clear reduction in naturally occurring cell death as demonstrated by TUNEL staining (bright dots) in regions in which malformations are observed (e), compared with control embryos (d). $n p$, anterior neuropore; ov optic vesicles. Reprinted with permission from EMBO J [64] (copyright 2003, Macmillan Publishers). f-h In ovo treatment with insulin receptor antisense oligodeoxynucleotides $(A S I R)$ for $10 \mathrm{~h}$ increased the proportion of apoptotic cells compared to control embryos incubated with random oligodeoxynucleotides (IR RAN) or untreated embryos (in vivo). Reprinted with permission from [48] (copyright 2002, The American Diabetes Association)

pancreatic insulin expression and function in humans may unravel relevant clinical implications. For example, it is important to characterise the proinsulin mRNA final protein product in non-pancreatic tissues, particularly when trying to generate insulin-secreting pancreatic betalike cells derived from stem cells, a complex and debated strategy [77-81]. Further, high glucose levels induce apoptotic cell death in the mouse pre-implantation embryo $[82,83]$ and during neurulation [84]. Deregulated cell death occurs in the genesis of diabetic embryopathy [8286], an observation that is consistent with the essential role of programmed cell death in embryonic development [8789]. It is nonetheless likely that congenital malformations are the result of diverse types of aberrant signals $[90,91]$ and not only the consequence of maternal hyperglycaemia. Indeed, congenital defects are still more frequent in infants of diabetic mothers than in the general population, in spite of adequate hyperglycaemia control in a large proportion of diabetic pregnant women. Recent reports have observed
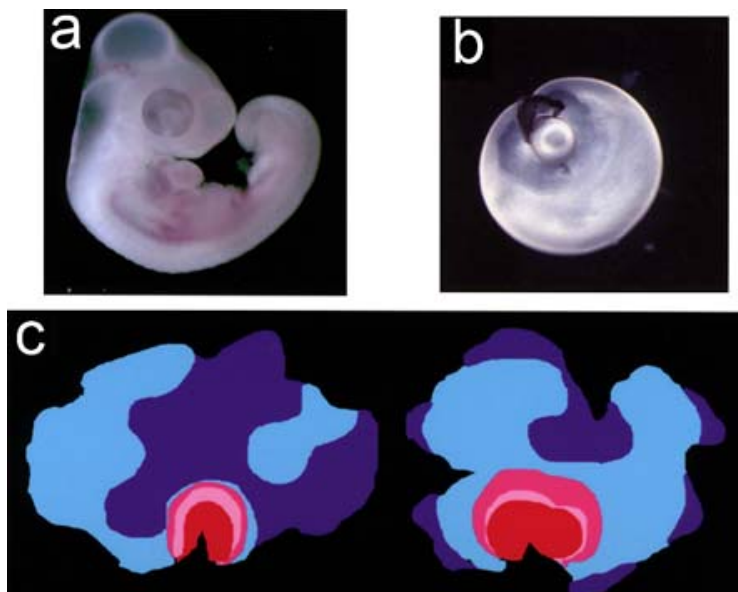

anti-Ins

anti-IR

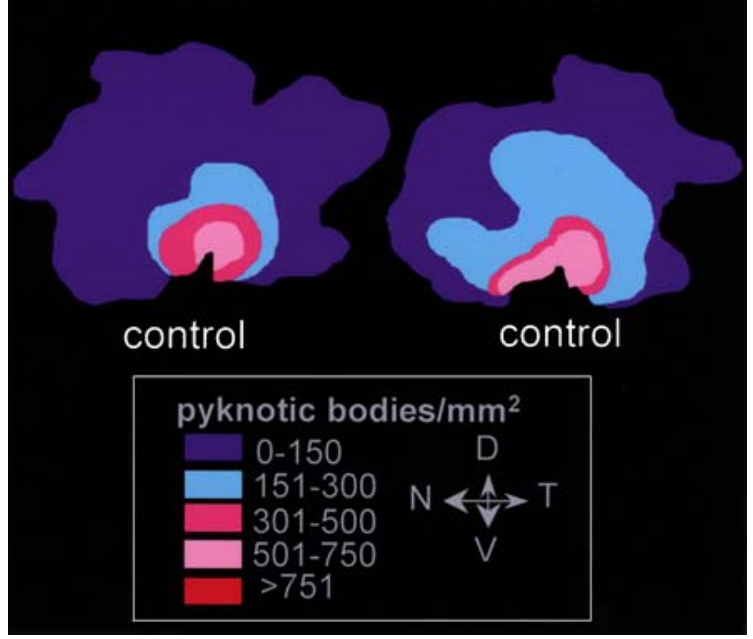

Fig. 5 Insulin function in the developing neuroretina. a E4 chick embryo; b dissected E4 neuroretina with the lens still in place; c isothanas representing density of TUNEL-stained cells per square $\mathrm{mm}$ of E4 chick neuroretinas previously treated in ovo with antiproinsulin/insulin Igs (Anti-Ins), anti-insulin receptor Igs (Anti-IR) antibodies or the corresponding control Igs (Control) for 2 days. Orientation of the retinas is indicated: $D$, dorsal; $V$, ventral; $N$, nasal; $T$, temporal. Reprinted with permission from [51]

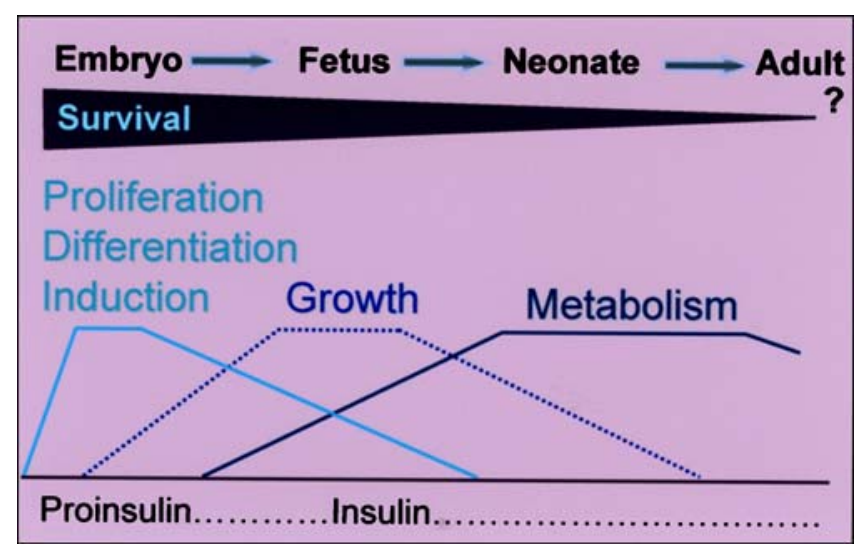

Fig. 6 Schematic overview of the proposed main influence of proinsulin and insulin as development proceeds. The idealised waves correspond to major processes or types of roles. The cell survival effect may underlay and facilitate others, and may be important in certain type of cells until advanced life 
that the correlation between congenital malformations in infants of diabetic mothers and pre-pregnancy BMI is higher than that between congenital malformations and maternal blood glucose values [92], and that oxidative stress makes an important contribution to the increase in neural tube defects [93]. In addition, obesity and hyperinsulinaemia have been suggested as risk factors for neural tube defects in the general population [94]. We anticipate that changes in proinsulin expression in placenta and fetal tissues may be among the risk factors during pregnancy in diabetic and obese women. Difficult as it may be to approach direct analysis in humans, it is necessary to continue unravelling the unexpected, physiological role of proinsulin in development with a naïve sense of wonder.

Acknowledgements Studies in the laboratory were funded by Red de Grupos RGDM G03/212 from the Instituto de Salud Carlos III (Spain), and BFU2004-2352 from the Spanish Ministry of Education and Science (MEC) to F. de Pablo; by BMC2003-07751 and SAF2004-05870 from MEC to E. J. de la Rosa; and by Comunidad de Madrid SAL/0647/2004 to C. Hernández-Sánchez. A. Mansilla was awarded a fellowship and C. Hernández-Sánchez was awarded the Ramón y Cajal contract (both by the MEC). We thank the former and present graduate students and postdoctoral fellows of our laboratory for working with enthusiasm on an unorthodox project. We also thank A. Robles for her major support to the group on a daily basis.

Duality of Interest The authors have no conflicts of interest regarding their research activities.

\section{References}

1. Robert JS, Hall BK, Olson WM (2001) Bridging the gap between developmental systems theory and evolutionary developmental biology. Bioessays 23:954-962

2. LeRoith D, Lesniak MA, Roth J (1981) Insulin in insects and annelids. Diabetes 30:70-76

3. Underhill LH, Rosenzweig JL, Roth J, Brownstein MJ, Young WS, Havrankova J (1982) Insulin and insulin receptors in the nervous system of mammals. Front Horm Res 10:96-110

4. Brogiolo W, Stocker H, Ikeya T, Rintelen F, Fernandez R, Hafen E (2001) An evolutionarily conserved function of the Drosophila insulin receptor and insulin-like peptides in growth control. Curr Biol 11:213-221

5. Pierce SB, Costa M, Wisotzkey R et al (2001) Regulation of DAF-2 receptor signaling by human insulin and ins-1, a member of the unusually large and diverse $C$. elegans insulin gene family. Genes Dev 15:672-686

6. De Meyts P (2004) Insulin and its receptor: structure, function and evolution. Bioessays 26:1351-1362

7. Sanger F (1959) Chemistry of insulin: determination of the structure of insulin opens the way to greater understanding of life processes. Science 129:1340-1344

8. Bottenstein JE, Sato GH (1979) Growth of a rat neuroblastoma cell line in serum-free supplemented medium. Proc Natl Acad Sci USA 76:514-517

9. Orci L (1985) The insulin factory: a tour of the plant surroundings and a visit to the assembly line. The Minkowski lecture 1973 revisited. Diabetologia 28:528-546

10. Steiner DF, Bell GI, Tager HS (1990) Chemistry and biosynthesis of pancreatic protein hormones. In: De Groot LJ (ed) Endocrinology. WB Saunders, Philadelphia, pp 1263-1289
11. Rhodes CJ (2000) Processing of the insulin molecule. In: LeRoith D, Taylor SI, Olefsky JM (eds) Diabetes mellitus: a fundamental and clinical text. Lippincott Williams \& Wilkins, Philadelphia, pp 20-338

12. Bathgate RA, Samuel CS, Burazin TC et al (2002) Human relaxin gene $3(\mathrm{H} 3)$ and the equivalent mouse relaxin (M3) gene. Novel members of the relaxin peptide family. J Biol Chem 277:1148-1157

13. Chan SJ, Steiner DF (2000) Insulin through the ages: phylogeny of a growth promoting and metabolic regulatory hormone. Am Zool 40:213-222

14. Rinderknecht E, Humbel RE (1978) The amino acid sequence of human insulin-like growth factor I and its structural homology with proinsulin. J Biol Chem 253:2769-2776

15. Rinderknecht E, Humbel RE (1978) Primary structure of human insulin-like growth factor II. FEBS Lett 89:283-286

16. Ebina Y, Ellis L, Jarnagin K et al (1985) The human insulin receptor cDNA: the structural basis for hormone-activated transmembrane signalling. Cell 40:747-758

17. Ullrich A, Gray A, Tam AW et al (1986) Insulin-like growth factor I receptor primary structure: comparison with insulin receptor suggests structural determinants that define functional specificity. EMBO J 5:2503-2512

18. Dupont J, LeRoith D (2001) Insulin and insulin-like growth factor I receptors: similarities and differences in signal transduction. Horm Res 55(Suppl 2):22-26

19. Kim JJ, Accili D (2002) Signalling through IGF-I and insulin receptors: where is the specificity? Growth Horm IGF Res 12:84-90

20. De Pablo F, Scott LA, Roth J (1990) Insulin and insulin-like growth factor I in early development: peptides, receptors and biological events. Endocr Rev 11:558-577

21. White MF (2002) IRS proteins and the common path to diabetes. Am J Physiol Endocrinol Metab 283:E413-E422

22. Dupont J, Holzenberger M (2003) Biology of insulin-like growth factors in development. Birth Defects Res C Embryo Today 69:257-271

23. Varela-Nieto I, de la Rosa EJ, Valenciano AI, Leon Y (2003) Cell death in the nervous system: lessons from insulin and insulin-like growth factors. Mol Neurobiol 28:23-50

24. Steele RE, Lieu P, Mai NH, Shenk MA, Sarras MP (1996) Response to insulin and the expression pattern of a gene encoding an insulin receptor homologue suggest a role for an insulin-like molecule in regulating growth and patterning in Hydra. Dev Gene Evol 206:247-259

25. Chervitz SA, Aravind L, Sherlock G et al (1998) Comparison of the complete protein sets of worm and yeast: orthology and divergence. Science 282:2022-2028

26. Chan SJ, Cao QP, Steiner DF (1990) Evolution of the insulin superfamily: cloning of a hybrid insulin/insulin-like growth factor cDNA from amphioxus. Proc Natl Acad Sci USA 87:9319-9323

27. Pashmforoush M, Chan SJ, Steiner DF (1996) Structure and expression of the insulin-like peptide receptor from amphioxus. Mol Endocrinol 10:857-866

28. Nagamatsu S, Chan SJ, Falkmer S, Steiner DF (1991) Evolution of the insulin gene superfamily. Sequence of a preproinsulin-like growth factor cDNA from the Atlantic hagfish. J Biol Chem 266:2397-2402

29. Kimura KD, Tissenbaum HA, Liu Y, Ruvkun G (1997) daf-2, an insulin receptor-like gene that regulates longevity and diapause in Caenorhabditis elegans. Science 277:942-946

30. Tatar M, Kopelman A, Epstein D, Tu MP, Yin CM, Garofalo RS (2001) A mutant Drosophila insulin receptor homologue that extends life-span and impairs neuroendocrine function. Science 292:107-110

31. Holzenberger M, Dupont J, Ducos B et al (2003) IGF-1 receptor regulates lifespan and resistance to oxidative stress in mice. Nature 421:182-187

32. Rosenfeld RG (2003) Insulin-like growth factors and the basis of growth. N Engl J Med 349:2184-2186 
33. Hernandez-Sanchez C, Bartulos O, De Pablo F (2005) Proinsulin: much more than a hormone precursor in development. Rev Endocr Metab Disord 6:211-216

34. De Pablo F, Roth J (1990) Endocrinization of the early embryo: an emerging role for hormones and hormone-like factors. Trends Biochem Sci 15:339-342

35. De Pablo F, de la Rosa EJ (1995) The developing CNS: a scenario for the action of proinsulin, insulin and insulin-like growth factors. Trends Neurosci 18:143-150

36. Serrano J, Bevins CL, Young SW, De Pablo F (1989) Insulin gene expression in chicken ontogeny: pancreatic, extrapancreatic, and prepancreatic. Dev Biol 132:410-418

37. Shuldiner AR, De Pablo F, Moore CA, Roth J (1991) Two nonallelic insulin genes in Xenopus laevis are expressed differentially during neurulation in prepancreatic embryos. Proc Natl Acad Sci USA 88:7679-7683

38. Deltour L, Leduque P, Blume N et al (1993) Differential expression of the two nonallelic proinsulin genes in the developing mouse embryo. Proc Natl Acad Sci USA 90:527531

39. Schultz GA, Hogan A, Watson AJ, Smith RM, Heyner S (1992) Insulin, insulin-like growth factors and glucose transporters: temporal patterns of gene expression in early murine and bovine embryos. Reprod Fertil Dev 4:361-371

40. Muglia L, Locker J (1984) Extrapancreatic insulin gene expression in the fetal rat. Proc Natl Acad Sci USA 81:36353639

41. Giddings SJ, Carnaghi LR (1990) Selective expression and developmental regulation of the ancestral rat insulin II gene in fetal liver. Mol Endocrinol 4:1363-1369

42. Giddings SJ, King CD, Harman KW, Flood JF, Carnaghi LR (1994) Allele specific inactivation of insulin 1 and 2, in the mouse yolk sac, indicates imprinting. Nat Genet 6:310-313

43. de la Rosa EJ, Bondy CA, Hernandez-Sanchez C et al (1994) Insulin and insulin-like growth factor system components gene expression in the chicken retina from early neurogenesis until late development and their effect on neuroepithelial cells. Eur J Neurosci 6:1801-1810

44. Alarcon C, Serna J, Perez-Villamil B, De Pablo F (1998) Synthesis and differentially regulated processing of proinsulin in developing chick pancreas, liver and neuroretina. FEBS Lett 436:361-366

45. Moore GE, Abu-Amero SN, Bell G et al (2001) Evidence that insulin is imprinted in the human yolk sac. Diabetes 50:199203

46. Morales AV, Serna J, Alarcon C, de la Rosa EJ, De Pablo F (1997) Role of prepancreatic (pro)insulin and the insulin receptor in prevention of embryonic apoptosis. Endocrinology 138:3967-3975

47. Diaz B, Pimentel B, De Pablo F, de la Rosa EJ (1999) Apoptotic cell death of proliferating neuroepithelial cells in the embryonic retina is prevented by insulin. Eur $\mathrm{J}$ Neurosci $11: 1624-1632$

48. Hernandez-Sanchez C, Rubio E, Serna J, de la Rosa EJ, De Pablo F (2002) Unprocessed proinsulin promotes cell survival during neurulation in the chick embryo. Diabetes 51:770-777

49. Scavo LM, Serrano J, Roth J, De Pablo F (1991) Genes for the insulin receptor and the insulin-like growth factor I receptor are expressed in the chicken embryo blastoderm and throughout organogenesis. Biochem Biophys Res Commun 176:13931401

50. Girbau M, Bassas L, Alemany J, De Pablo F (1989) In situ autoradiography and ligand-dependent tyrosine kinase activity reveal insulin receptors and insulin-like growth factor I receptors in prepancreatic chicken embryos. Proc Natl Acad Sci USA 86:5868-5872

51. Diaz B, Serna J, De Pablo F, de la Rosa EJ (2000) In vivo regulation of cell death by embryonic (pro)insulin and the insulin receptor during early retinal neurogenesis. Development 127:1641-1649

52. Kelly RB (1985) Pathways of protein secretion in eukaryotes. Science 230:25-32
53. Hernandez-Sanchez C, Lopez-Carranza A, Alarcon C, de la Rosa EJ, De Pablo F (1995) Autocrine/paracrine role of insulinrelated growth factors in neurogenesis: local expression and effects on cell proliferation and differentiation in retina. Proc Natl Acad Sci USA 92:9834-9838

54. Garcia-de Lacoba M, Alarcon C, de la Rosa EJ, De Pablo F (1999) Insulin/insulin-like growth factor-I hybrid receptors with high affinity for insulin are developmentally regulated during neurogenesis. Endocrinology 140:233-243

55. Soos MA, Field CE, Siddle K (1993) Purified hybrid insulin/ insulin-like growth factor-I receptors bind insulin-like growth factor-I, but not insulin, with high affinity. Biochem J 290:419426

56. Bailyes EM, Nave BT, Soos MA, Orr SR, Hayward AC, Siddle K (1997) Insulin receptor/IGF-I receptor hybrids are widely distributed in mammalian tissues: quantification of individual receptor species by selective immunoprecipitation and immunoblotting. Biochem J 327:209-215

57. Pandini G, Frasca F, Mineo R, Sciacca L, Vigneri R, Belfiore A (2002) Insulin/insulin-like growth factor I hybrid receptors have different biological characteristics depending on the insulin receptor isoform involved. J Biol Chem 277:3968439695

58. Leibiger B, Moede T, Schwarz T et al (1998) Short-term regulation of insulin gene transcription by glucose. Proc Natl Acad Sci USA 95:9307-9312

59. Brunstedt J, Chan SJ (1982) Direct effect of glucose on the preproinsulin mRNA level in isolated pancreatic islets. Biochem Biophys Res Commun 106:1383-1389

60. Permutt MA (1974) Effect of glucose on initiation and elongation rates in isolated rat pancreatic islets. $\mathrm{J}$ Biol Chem 249:2738-2742

61. Itoh N, Okamoto H (1980) Translational control of proinsulin synthesis by glucose. Nature 283:100-102

62. Welsh M, Scherberg N, Gilmore R, Steiner DF (1986) Translational control of insulin biosynthesis. Evidence for regulation of elongation, initiation and signal-recognitionparticle-mediated translational arrest by glucose. Biochem J 235:459-467

63. Perez-Villamil B, de la Rosa EJ, Morales AV, De Pablo F (1994) Developmentally regulated expression of the preproinsulin gene in the chicken embryo during gastrulation and neurulation. Endocrinology 135:2342-2350

64. Hernandez-Sanchez C, Mansilla A, de la Rosa EJ, Pollerberg GE, Martinez-Salas E, De Pablo F (2003) Upstream AUGs in embryonic proinsulin mRNA control its low translation level. EMBO J 22:5582-5592

65. Geballe AP, Sachs MS (2000) Translational control by upstream open reading frames. In: Sonenberg N, Hershey JW, Mathews MB (eds) Translational control of gene expression. Cold Spring Harbor Laboratory, New York, pp 595-614

66. Morris DR, Geballe AP (2000) Upstream open reading frames as regulators of mRNA translation. Mol Cell Biol 20:86358642

67. Kozak M (2002) Pushing the limits of the scanning mechanism for initiation of translation. Gene 299:1-34

68. De Pablo F, Hernandez E, Collia F, Gomez JA (1985) Untoward effects of pharmacological doses of insulin in early chick embryos: through which receptor are they mediated? Diabetologia 28:308-313

69. Mansilla A, Lopez-Sanchez C, de la Rosa EJ et al (2005) Developmental regulation of a proinsulin messenger RNA generated by intron retention. EMBO Rep 12:1182-1187

70. Rosenfeld RG, Roberts CT (eds) (1999) The IGF system: molecular biology, physiology and clinical applications. Humana, Totowa

71. De Pablo F, Girbau M, Gomez JA, Hernandez E, Roth J (1985) Insulin antibodies retard and insulin accelerates growth and differentiation in early embryos. Diabetes 34:1063-1067

72. Travers JP, Pratten MK, Beck F (1989) Effects of low insulin levels on rat embryonic growth and development. Diabetes $38: 773-778$ 
73. Lough J, Sugi Y (2000) Endoderm and heart development. Dev Dyn 217:327-342

74. Patwardhan V, Gokhale M, Ghaskadbi S (2004) Acceleration of early chick embryo morphogenesis by insulin is associated with altered expression of embryonic genes. Int J Dev Biol 48:319326

75. Kitamura T, Kahn CR, Accili D (2003) Insulin receptor knockout mice. Annu Rev Physiol 65:313-332

76. Robbins DC, Tager HS, Rubenstein AH (1984) Biologic and clinical importance of proinsulin. N Engl J Med 310:11651175

77. Lumelsky N, Blondel O, Laeng P, Velasco I, Ravin R, McKay R (2001) Differentiation of embryonic stem cells to insulinsecreting structures similar to pancreatic islets. Science 292:1389-1394

78. Rajagopal J, Anderson WJ, Kume S, Martinez OI, Melton DA (2003) Insulin staining of ES cell progeny from insulin uptake. Science 299:363

79. Hori Y, Rulifson IC, Tsai BC, Heit JJ, Cahoy JD, Kim SK (2002) Growth inhibitors promote differentiation of insulinproducing tissue from embryonic stem cells. Proc Natl Acad Sci USA 99:16105-16110

80. Blyszczuk P, Czyz J, Kania G et al (2003) Expression of Pax4 in embryonic stem cells promotes differentiation of nestinpositive progenitor and insulin-producing cells. Proc Natl Acad Sci USA 100:998-1003

81. Roche E, Sepulcre P, Reig JA, Santana A, Soria B (2005) Ectodermal commitment of insulin-producing cells derived from mouse embryonic stem cells. FASEB J 19:1341-1343

82. Moley KH, Chi MM, Knudson CM, Korsmeyer SJ, Mueckler MM (1998) Hyperglycemia induces apoptosis in pre-implantation embryos through cell death effector pathways. Nat Med 4:1421-1424

83. Moley KH (2001) Hyperglycemia and apoptosis: mechanisms for congenital malformations and pregnancy loss in diabetic women. Trends Endocrinol Metab 12:78-82
84. Fine EL, Horal M, Chang TI, Fortin G, Loeken MR (1999) Evidence that elevated glucose causes altered gene expression, apoptosis, and neural tube defects in a mouse model of diabetic pregnancy. Diabetes 48:2454-2462

85. Pampfer S, Vanderheyden I, McCracken JE, Vesela J, De Hertogh R (1997) Increased cell death in rat blastocysts exposed to maternal diabetes in utero and to high glucose or tumor necrosis factor-alpha in vitro. Development 124:48274836

86. Phelan SA, Ito M, Loeken MR (1997) Neural tube defects in embryos of diabetic mice: role of the Pax-3 gene and apoptosis. Diabetes 46:1189-1197

87. Kuida K, Zheng TS, Na S et al (1996) Decreased apoptosis in the brain and premature lethality in CPP32-deficient mice. Nature 384:368-372

88. de la Rosa EJ, De Pablo F (2000) Cell death in early neural development: beyond the neurotrophic theory. Trends Neurosci $23: 454-458$

89. Vaux DL, Korsmeyer SJ (1999) Cell death in development. Cell 96:245-254

90. Schwartz R, Teramo KA (1996) Pregnancy: outcomes in the diabetes control and complications trial. Am J Obstet Gynecol 174:1343-1353

91. Chang TI, Loeken MR (1999) Genotoxicity and diabetic embryopathy: impaired expression of developmental control genes as a cause of defective morphogenesis. Semin Reprod Endocrinol 17:153-165

92. Garcia-Patterson A, Erdozain L, Ginovart G et al (2004) In human gestational diabetes mellitus congenital malformations are related to pre-pregnancy body mass index and to severity of diabetes. Diabetologia 47:509-514

93. Li R, Chase M, Jung SK, Smith PJ, Loeken MR (2005) Hypoxic stress in diabetic pregnancy contributes to impaired embryo gene expression and defective development by inducing oxidative stress. Am J Physiol Endocrinol Metab 289:E591-E599

94. Hendricks KA, Nuno OM, Suarez L, Larsen R (2001) Effects of hyperinsulinemia and obesity on risk of neural tube defects among Mexican Americans. Epidemiology 12:630-635 